\title{
Open Innovation in Services? A Conceptual Model of Barriers to Service Innovation Adoption
}

ISSN: 2183-0606

(CC BY 3.0)

Vol. 9, 4 (2021)

p. $58-79$

AM: Nov/2021

SM: Jul $/ 2020$

\author{
Jeff Moretz ${ }^{1}$, Karthik Sankaranarayanan ${ }^{2}$, and Jennifer Percival ${ }^{3}$ \\ ${ }^{1}$ Fairfield University, Management Department, Fairfield, CT, United States | jmoretz@fairfield.edu \\ ${ }^{2}$ Ontario Tech University, Faculty of Business and Information Technology, Oshawa, Ontario, Canada | \\ karthik.sankaranarayanan@ontariotechu.ca \\ ${ }^{3}$ University of Massachusetts Lowell, Manning School of Business, Lowell, MA, United States | \\ Jennifer_Percival@uml.edu
}

\begin{abstract}
Recently, there has been an increased focus on the service sector as a source for economic growth and development. This is particularly true in the knowledge-based services where the need for innovative service offerings in the global market continues to grow. The open innovation model is one which has been gaining in popularity as the technology continues to improve the ability for global collaborations and partnerships. The concept of open innovation is increasingly researched, however less is known about open service innovation, and the perception that open service innovation lags open product innovation persists. This paper presents an extension of existing models of open innovation focusing on the interplay between innovation sources and diffusion of open service innovations. Particular attention is paid to the potential barriers in order to demonstrate the additional complexities in managing open service innovations in comparison to their physical good counterparts. The conceptual model provides insight into areas for future research at the individual, meso-, and macro-levels to better understand the factors that influence open services innovation, situations in which open innovation is most practical, and intricacies necessary to support open innovation in services.
\end{abstract}

Keywords: Open Innovation; Open Innovation Adoption; Open Service Innovation; Innovation Barriers; Service Industry; Diffusion of Innovations.

Cite paper as: Moretz, J., Sankaranarayanan, K., Percival, J., (2021). Open Innovation in Services? A Conceptual Model of Barriers to Service Innovation Adoption, Journal of Innovation Management, 9(4), 58-79.; DOI: https://doi.org/10.24840/2183-0606_009.004_0004

\section{Introduction}

Many firms, particularly in developed countries, are looking to the service sector for growth in the ever increasingly competitive global environment. The prominence of the service sector (particularly the knowledge-based services) in the global economy is increasing, consequently making innovation in this sector a matter of greater importance (Gallouj and Weinstein, 1997; Randhawa and Scerri, 2015). There is a large and diverse amount of literature regarding innovation in firms, much of it related to product innovations in manufacturing organizations (Brown and Eisenhardt, 1995). When compared to product innovation, there have been relatively few studies that have focused specifically on innovation in the service sector (e.g., Djellal and Gallouj, 2001; Evangelista and Savona, 2003, 2010; Tidd and Hull, 2003; Prajogo, 2006), and many of these examinations of service innovation have focused on defining the theoretical differences between innovation in manufacturing and services. 
Management of open and distributed innovation activities is of critical importance (Ollila and Elmquist, 2011; Bogers and West, 2012), yet the process of innovation management in service firms differs from that of manufacturers due to the importance of a variety of organizational knowledge capabilities to support the creation of value (Lichtenthaler and Lichtenthaler, 2009). In particular, few service firms have formal research and development units compared to their manufacturing counterparts (Sundbo, 1997) and therefore only a small percentage of service innovations are as a result of strategically planned actions (Kohler et al., 2013). With regards to the greater need of service firms to leverage co-creation of value, innovative services are often derived from the use of on-going relationships, intensive communication, and customer intimacy (Chesbrough, 2003a; Chen et al., 2009; Giannopoulou et al., 2011; Gustafsson et al., 2012). Moeller et al. (2013) examine such co-creation, focusing on the role of customer participation and collaborative value creation in services, and Ordanini and Parasuraman (2010) look at both customer and business-partner collaboration in their exploration of service innovation outcomes.

The need to evaluate and build knowledge capabilities in the firm is of critical importance in cases of open innovation (Lichtenthaler and Lichtenthaler, 2009). For service organizations in particular, the existing gap between the perceived importance of innovation and the ability to carry out an assessment of the organization's knowledge capabilities is a critical area for improving a firm's competitive advantage (Ganz et al., 2012; Kohler et al., 2013). Such issues are further compounded when we consider the domain of open service innovation, where there is a significant lack of tools or frameworks, a challenge that this paper attempts to help address.

The paper is structured as follows. In the next section, we review the background literature regarding service innovation and open innovation. We then describe the constraints around innovation diffusion as applied to open innovation. Next, the findings from the review of open innovation systems are used to define a conceptual model of open service innovation, particularly the barriers to wider adoption and diffusion of such innovations. Finally, we present our vision of future development and research challenges in the area of open service innovation.

\section{Methodology}

Our primary interest was in open service innovation, particularly the differences that seem to obtain between open innovation in services and open product innovation. We focused our search on two prominent databases of scholarly work: Clarivate Analytics - Web of Science and Elsevier's ScienceDirect. The broad area of innovation scholarship is well represented, with a search for "innovation" in title/abstract/keyword fields yielding 215,478 papers/proceedings/book chapters in Web of Science (WoS) and 48,032 results in ScienceDirect (SD), with a very high proportion of duplicates. A search in WoS for "open innovation" produced 2,713 articles, 1,328 proceedings, and 6 book chapters. In order to develop a tractable set of papers focused on our research interest, we searched using the string "open service innovation" and analogs (e.g., "open innovation in services"), which resulted in 31 papers (26 in WoS and 7 in SD, 2 of which were duplicates). The most specific search strings, "open service innovation" (and analogs) combined with "barriers" and "diffusion," resulted in one paper in each database. Within our search for open service innovation papers, 20 (nearly 2/3) were published since 2015, showing the increasing scrutiny that this area has garnered in the last few years. However, despite this increased attention, our review reveals the underrepresentation of focused examinations of open service innovation and the issues that produce the observed lag relative to open product innovation. It is precisely this dearth of focused examination that this manuscript attempts to help address. 


\section{Innovation}

For most of the 20th century firms relied upon what has been styled the closed innovation model (Chesbrough, 2003a; Lichtenthaler, 2011) in order to maintain competitiveness. Under this approach to innovation, firms relied upon internal resources which includes human and technological capabilities to come up with innovative products. The period between the end of World War II and the 1990's saw widespread use of closed innovation models, wherein big firms invested enormous capital in setting up captive cutting edge research labs. This competitive strategy relied on strong intellectual property protection and warded away competition from smaller firms that lacked the resources to undertake such projects. Chesbrough (2003a) presents a detailed picture of IBM as a prototypical example of this approach to innovation activities from the post-war economic boom until the end of the 1980's. Also, the "not invented here" syndrome (Katz and Allen, 1982) was prevalent among decision makers who often considered anything coming from outside the boundaries of the firm to be highly suspicious. Reliability was another factor that concerned the decision makers. Hence innovation was overwhelmingly conducted internally, and innovations were protected vigorously under intellectual property law. The literature on innovation mostly revolved around new product development and plethora of studies concentrated on the manufacturing sector (Brown and Eisenhardt, 1995).

There has been extensive exploration of the factors that influence organizational innovation. With a focus on innovation in modes of organization, Chandler's monograph on strategy and structure (1962) dedicated an entire chapter to organizational innovation. Responding to instability in reported findings regarding innovation factors, Downs and Mohr (1976) examined numerous aspects on innovations and organizations, arguing that the appropriate unit of analysis is the conjunction of the innovation and the organization. Miller and Friesen (1982), in their study of conservative and entrepreneurial product innovation, identified four categories of influencing factors: environmental, information processing, structural, and decision-making. Damanpour's (1991) meta-analysis of hypothesized determinants of innovation and organizational innovation outcomes examines a wide range of organizational attributes and their relationships to innovation, including investigation of four categories of moderators, using a sample of studies of multiple innovations.

Crossan and Apaydin (2010) published an extensive literature review of research on innovation, focusing on the process and outcomes of innovation, as well as the impact of leadership. In a broad examination of innovation and creativity research. Anderson et al. (2014) identified six theoretical frameworks and numerous perspectives addressing creativity and innovation at different levels of analysis. Subsequent research has examined individual level factors involved in innovation (e.g., Amabile \& Pratt, 2016; Wallace et al., 2016), and organizational influences (e.g., Vuori \& Huy, 2016) with some arguing that organizations need to develop innovation strategies (Pisano, 2015), as well as the impact of broader societal culture (see Tian et al., 2017 for an extensive review). Although the factors that influence corporate innovation have been extensively researched, open innovation and related concepts have only recently begun to attract significant scholarly attention (Chesbrough, 2003b; Von Hippel, 2005; Chesbrough et al., 2006), and open service innovation has received very limited attention (Chesbrough, 2010).

\subsection{Open Innovation}

The beginning of the 21st century ushered in new challenges into the corporate world. Big firms could not control or even hold onto their human capital because workers had become highly mobile (Huizingh, 2011). Also, the availability of external sources of funding through venture capital resulted in an explosion of start-ups, presenting significant challenges for closed innovation 
models. Research labs were not confined to big firms as smaller firms were increasing their innovation activities. These smaller firms often utilized collaboration and alliances to improve the chances of commercializing their innovations. While the underlying concepts were not entirely new, Chesbrough (2003a) gave a name to the collection of inbound and outbound collaborations and other sharing relationships, dubbing this approach "open innovation."

Chesbrough's open innovation term (2003b) has caught the attention of researchers since he introduced it in 2003. Chesbrough posits that organizations, in addition to leveraging internal resources to facilitate innovation, should look for external sources of knowledge and innovative ideas (Chesbrough, 2003a; 2004; Chesbrough and Crowther, 2006). In the globalized economy, firms collaborate, share intellectual property, and also use external and internal paths in order to commercialize their innovation (Huizingh, 2011), although much research has focused on the sourcing of innovation rather than its commercialization (West \& Bogers, 2014). Firms use a mix of exploration and exploitation strategies (March, 1991; Lichtenthaler, 2011; Gould 2012) as they seek to utilize external sources of knowledge to stay competitive. Researchers including Faems et al. (2005), Dahlander and Gann (2010), and De Faria et al. (2010) have pointed out that firms cannot innovate in isolation and need to engage with external partners in order to stay abreast with competition, in particular due to the wide distribution of information relevant to innovation (von Hippel, 2005; Chesbrough, 2006; Bogers \& West, 2012).

A plethora of research papers has arisen around this topic as researchers attempt to define openness and identify how organizations can leverage openness and benefit from this approach to innovation (Dahlander and Gann, 2010; Huizingh, 2011). A review of articles in Clarivate's "Web of Science" database shows the growth in research addressing open innovation in various forms, with more than half of the items published since 2016. Articles attend to open innovation issues under a wide variety of research domains including absorptive capacity, knowledge management, alliances, role of intermediaries, etc. Huizingh (2011) points out that the concept of open innovation is not clear cut, and researchers have tackled it from various angles adding to the fuzziness. Thus, he argues for the need to develop a framework for tackling open innovation issues. Fernandes et al. (2019), in an extensive bibliometric review, identified six perspectives taken in researching open innovation: open innovation concept, open innovation and networks, open innovation and knowledge, open Innovation, and innovation spillovers, open innovation management and open innovation and technology.

Although there have been a number of articles written recently exploring open innovation, particularly in the high technology sector, despite the publication of many papers subsequent to Chesbrough's (2011a, 2011b, 2011c) calls for research into open innovation in services, fewer papers have addressed the specific challenges of open innovation in the services sector. A recent special issue in the Journal of Product Innovation Management (volume 35, issue 5, September 2018) has helped to address this gap, but there has been little exploration of obstacles or barriers that might explain the lag of open service innovation when compared with product innovation.

\subsection{Openness and Innovation Risks}

One important aspect that any move to adopt more open innovation practices must address is the concomitant changes in business risk. One of the more commonly used classifications of risk in discussions of innovation has been the dichotomy of technological risk and market risk. Technology risk has been addressed extensively, in particular within the transaction cost literature, with much research focusing on the possibility of holdup situations arising because of proprietary technology (Walker and Weber, 1984). The importance of the creation and utilization of knowledge in the innovation process means that additional risks may play important roles when 
addressing knowledge and knowledge transfers (Grant, 1996b; Grant, 1996a).

Two distinct technology risks can be distinguished. Technological change that renders existing firm technology less effective may reduce the firm's competitiveness, and the ownership of proprietary technology by critical suppliers may give them advantages leading to greater bargaining power. Robertson and Gatignon (1998) addresses uncertainty with respect to technological development, highlighting the fact that firms seem to be less likely to vertically integrate when technology risk is high. This may be due to firms seeking the flexibility that partnerships and alliances may provide and the increased knowledge gain from wider search and interaction with market participants in order to deal more quickly and effectively with the changes that crop up in dynamic environments. Thus, the broader search that an open innovation approach implies should increase a firm's capacity to recognize and react to technological change. Issues regarding proprietary supplier technology may be similarly ameliorated by leveraging the advantages of openness. If the firm is able to identify feasible substitutes for those proprietary technologies, the bargaining power of suppliers would be constrained. These advantages complement the advantage with respect to speed to market. Broader search for relevant knowledge should promote better information flow, facilitating more rapid and effective development of products and services, thereby decreasing time to market issues (Teece, 1992). Thus, openness represents a net benefit by providing opportunities to reduce firm risks regarding technological change and proprietary technology.

Demand uncertainty is perhaps the most readily recognizable type of market risk, and it is addressed at length in the transaction cost literature (Williamson, 1981; Walker and Weber, 1984). When confronted with demand uncertainty, firms often purchase inputs rather than vertically integrating and making those inputs internally, though circumstances such as markets with minimal competition often lead to vertical integration (Walker and Weber, 1987). Demand uncertainty for the outputs of innovating firms exacerbates input sourcing issues while also causing problems such as over or under-investment in capacity (Arrow, 1962). Here again, the broader information search and sharing associated with openness may increase a firm's ability to forecast demand. More effective information acquisition also provides knowledge of additional avenues for marketing products and may promote enhanced flexibility in operations, increasing the advantages of openness for innovating firms.

Appropriation risk may also play a more significant role in open innovation development and adoption due to concerns regarding a potential lack of mechanisms to keep benefits within the firm (Chesbrough et al., 2018). For example, firm specific innovation has been linked to greater firm value appropriation (Wang \& Chen, 2010), although the mechanisms that promote appropriability may also inhibit innovation, itself (Hurmelinna et al., 2005). Some evidence suggests that firms that engage in greater openness also invest in often informal or process-based appropriation mechanisms in order to protect potential profitability (Henkel, 2006; Gould, 2012; Huang et al., 2014; Chesbrough et al., 2018).

The stream of literature that developed out of agency theory and agency logic addresses other types of risks that may arise in collaborations with other parties. For example, moral hazard and adverse selection may arise when firms hire external parties such as contractors to undertake work (Eisenhardt, 1989). If the contracting firm has insufficient information to determine the abilities of an agent before finalizing a contract or is unable to assess the agent's work afterward, the contracting process may break down. Thus, information is vitally important for effective contracting. Openness and the associated broader information search reduce the risk of adverse selection up front, and to the extent that increased information flow improves the firm's ability to assess the work of a contactor it also decreases moral hazard risk (Eisenhardt, 1989). 


\subsection{Service Innovation}

Economists have for a long time considered services as intangible goods, and they have largely neglected services while constructing economic theories. Hill (1977) defines goods as physical objects that are transferrable between economic units, and services as actions that bring about changes in the conditions of economic units. However, until recently most innovation research has glossed over the important differences between goods and services, focusing the lion's share of attention on innovation related to tangible goods. The study of services and innovation in services is of paramount importance considering the modern knowledge driven and therefore service oriented economies.

Until the 1980's, the services sector was considered non-innovative and a laggard in terms of adoption of technological innovation (Pavitt, 1984; Drejer, 2004; Chesbrough, 2011b). As the services sector started gaining a larger share of the economic pie in advanced economies, with services share of GDP more than doubling (OECD, 2007), innovation researchers started applying innovation theory to understand services. OECD, the Organization for Economic Co-operation and Development, states that services account for $80 \%$ of economic activity in the United States, and $60 \%$ of economic activity in the top 40 economies of the world (OECD, 2007). The services sector also accounts for over $70 \%$ of employment and value added in OECD economies (OECD, 2005). The services sector plays a prominent role in today's economy (Menor and Roth, 2007; O'Cass and Wetzels, 2018), yet innovation in services has been argued to be substantially less effective than innovation in products. Froehle, at al. (2000) argue that "when compared to tangible products, services are generally underdesigned and inefficiently developed." In the introduction to their volume covering a wide range of perspectives on service innovation, Agarwal et al. (2015) argue for greater attention to the challenges of managing service innovation "if productivity improvement in services is to keep up with the long-lasting productivity improvement in manufacturing" (p. xi)

Many scholars who have addressed service innovation argue that most prior research and associated theories were developed with a strong focus on the manufacturing sector (Gallouj and Weinstein, 1997; Howells, 2000; Drejer, 2004). Early studies of innovation in services leveraged theories and metrics from the well-established research in the technology-focused manufacturing domain. This approach has been dubbed the assimilation approach (Coombs and Miles, 2000; Drejer, 2004; Nijssen et al., 2006). One issue with studies of services is that measurement of innovation in services is difficult due to the intangible nature of the output unlike the manufacturing sector; hence, traditional economic measurement methods cannot readily be used (Menor and Roth, 2007). Gallouj and Savona (2009) points out systematic issues in the study of services innovation, and a recent study by Djellal and Gallouj (2013) addresses the challenges of measuring productivity in services.

A number of schools of thought exist regarding how to approach the study of service innovation, and scholars have made efforts to segment the existing service innovation literature (Coombs and Miles, 2000; Droege et al., 2009). Coombs and Miles (Coombs and Miles, 2000) put forth three choices that service innovation researchers should consider in their efforts to define and measure innovation: assimilation, demarcation, and synthesis. Fischer (2009) provides a graphical depiction of a similar segmentation, using the term distinction instead of demarcation.

The idea behind the assimilation perspective is that concepts and theories established for the study of manufacturing can readily be adapted to service innovation (Coombs and Miles, 2000; Droege et al., 2009). Researchers in this stream consider minimal differences between services and manufacturing, and they argue that innovation concepts from manufacturing can be easily mapped to the services sector. Many innovation theory experts feel that the assimilation school of thought does not consider the fuzzy nature of services and hence cannot be used to understand innovation 
in services. Scholars who approach services from the demarcation perspective argue that services have distinctive characteristics, hence requiring new theories and metrics to understand them (Gadrey et al., 1995; Nijssen et al., 2006). Researchers point out to the co-creative, intangible, and heterogeneous characteristics of services and argue that technology focused innovation theories will not suit service innovation studies. Those pursuing research leveraging the synthesis school of thought contend that services and products are intertwined, hence the need to study them together rather than separately (de Vries, 2006; Castro et al., 2011). Gallouj and Weinstein (1997) were among the pioneers in this relatively new stream of service innovation research. They utilize Lancaster's (1966) definition of a product as a set of characteristics, allowing them to avoid definitional issues leading to the separation of products from services (demarcation).

Finally, Droege et al. (2009), propose a fourth school of thought, namely the technological perspective. As the name indicates, technological advances, adoption, and progress are factors considered for the measurement of service innovation. Barras' (1986) reverse product life cycle is considered by scholars as the starting point for this line of thought. Critics of this perspective argue that many services are not technology focused. Thus, they contend that this school of thought allows only the assessment of technologically enabled services, rendering it useless for the study of other types of services.

\subsection{Co-creation, Servitization, and Open Service Innovation}

Chesbrough's open innovation paradigm argues that "Firms can and should use external ideas, and internal and external paths to market, as the firms look to advance their technology" (2003b, p. xxiv). Extending this idea of openness to services, Chesbrough (2010; 2011a; 2011c) asserted the need to confront the limitations of product focused innovation and the necessity to rethink how to innovate. This framework is a generic one and focuses attention on co-creation, customization, and the need to rethink business models in order to achieve service innovation. Chesbrough and Spohrer (2006) expanded on the issues that a service context evokes, arguing the need for a new research domain in order to tackle services adequately. In an extensive review of service innovation, Randhawa and Scerri (2015) point out many issues that researchers and practitioners of service innovation face, including the simultaneous production, delivery, and consumption of most services, the high degree of customer-provider interaction (cf., co-creation), and the intangible nature of services, what Alexiev et al. (2015) call simultaneity, heterogeneity, and intangibility, all of which make untangling and managing these activities more challenging.

Simultaneity, particularly as it relates to high customer-provider interaction, is linked to the concept of co-creation (Kambil et al., 1996; Kambil et al., 1999). Prahalad and Ramaswamy (2004) expanded on the concept, extending the thoughts developed in their early article "Co-opting Customer Competence" (2000). This approach argues that value is created in conjunction with customers rather than autonomously, in isolation from them. Much early exploration of co-creation explored internet facilitated user involvement in communities and crowdsourcing efforts (Wittke and Hanekop, 2011). This research is related to the extensive literature on open source software development (Feller and Fitzgerald, 2002) as those efforts, at least for projects that leverage peer-production (Benkler, 2002), often rely extensively on such community and crowdsourcing efforts. For example, similar to a central concern in many open source studies, some innovation scholars have examined motivation of consumers to participate in co-creation (Füller, 2010; Fernandes and Remelhe, 2016).

Some researchers have leveraged the service-dominant logic framework for value creation (Lusch and Vargo, 2014; Lusch and Nambisan, 2015) to argue that such co-creation is active in any interaction between customer and firm, doing so using terms such as customer engagement 
(Verhoef et al., 2010; Brodie et al., 2011) as well as co-creation (Vargo et al., 2008; Jaakkola and Alexander, 2014). Indeed, the entire phenomenon of co-creation has been described as an example of service innovation (Edwards, et al., 2015) and is necessarily of a more open character. Many recent explorations of open service innovation have also employed the concept of servitization (Kroh et al., 2018; Goduscheit and Faullant, 2018). Servitization (Vandermerwe and Rada, 1988; Baines et al., 2009) argues that products and services are sold as an integrated bundle.

The increasing attention to co-creation, servitization, and other treatments of the bundling along with the blurring of the lines between product and service, means that as we develop our understanding of open innovation in products, the related development of open innovation in services is of central importance. This paper is in line with the current trend seeking to understand innovation in services, and we propose a high level model for exploring barriers to the utilization of knowledge sources in innovation activities and to the application and diffusion of service innovations, in particular.

\section{Diffusion of Innovations}

Diffusion of innovations comprises a very broad assortment of research addressing myriad different perspectives on innovation. The seminal work of Rogers (1962) addressed the spread of innovations over time using four primary dimensions: the innovation itself, the communication channel(s) used, time, and the social system within which the innovation spread. Roger's work focused on technology, using the terms in the general sense of an approach to transforming inputs into outputs, making his conceptualization applicable across a broad range of innovation adoption contexts. Rogers invokes both hardware, the physical manifestations of innovation, and software, or the information and knowledge associated with the innovation.

As Rogers points out, innovation adopters can be idealized into categories moving from the innovators themselves, those who create innovative technologies, on the cutting edge of innovation through early adopters, early majority, and late majority, to laggards who are slow to adopt new products and processes. The division of innovation adoption using standard deviations along a normal distribution has gained wide acceptance in the literature (cf. Abrahamson and Rosenkopf, 1993). Where an adopter falls along this scale may depend upon a number of characteristics of the adopter and the innovation. The model that Rogers (1962) promulgated argues that there are five stages of diffusion: knowledge, persuasion, decision, implementation, and confirmation.

\subsection{Knowledge}

The conception of knowledge in the revised Rogers model is more akin to Rogers' earlier concept of "awareness" than to the more involved knowledge conceptions that have arisen in more recent management literature. However, conceptions of knowledge such as those in Nonaka (1991; 1994), Nonaka and Takeuchi (1995), and Nonaka et al. (1996) are highly relevant to the concept of innovation and the adoption of innovations. Construing knowledge as the critical element of innovation, Nonaka (1994), Nonaka and Takeuchi (1995), and Nonaka et al. (1996) addressed the characteristics of knowledge creation and dissemination. The distinction between explicit knowledge, which can be codified, and tacit knowledge, which is embedded in an individual's experiences and activities, is central to the discussion of knowledge dissemination. According to this view, tacit knowledge presents barriers to rapid diffusion because of its analog character, making it resistant to ready dissemination in any written format. The importance of social interaction is also addressed, in particular with respect to the need for organizational legitimization of individual knowledge creation in order for a novel conception of or solution to a problem to 
be integrated into an institution's routines. Extending the work of scholars such as Wernerfelt (1984), Barney (2001) and Grant (1996b), Grant (1996a) and Kogut and Zander (1992) posited knowledge as the fundamental firm resource necessary for applying all other firm resources and capabilities. Thus, knowledge would be the primary component of any innovation. Assuming this primacy of knowledge, the question arises as to how knowledge is transferred to or acquired by institutions beyond those within which they arise.

\subsection{Absorptive Capacity}

The ability of a firm to recognize, understand, and apply new, innovative knowledge is tackled in the literature on absorptive capacity. As far back as 1958, March and Simon (1958) suggested that while innovations may be invented within an organization, it was likely that organizations would "borrow" innovations that arose outside the boundaries of the organization. Yet in order to borrow innovations, a firm must first be able to recognize and understand them. Such capacity has been assessed at multiple levels including national (Abramovitz, 1986; Kedia and Bhagat, 1988), inter-organizational (Inkpen and Tsang, 2005), intra-organizational (Tsai and Ghoshal, 1998; Argote and Ingram, 2000), and individual (Osterloh and Frey, 2000). Although all of the underlying learning "takes place inside individual human heads" (Simon, 1991), the relevant level at which an innovation is applied is generally the organization.

The absorptive capacity literature treats the inter-organizational and intra-organizational creation, transfer, and use of knowledge. Absorptive capacity refers to an organization's ability to assimilate and apply external learning to achieve desired outcomes. Cohen and Levinthal (1990) argue that although the absorptive capacity of an organization relies on the knowledge and learning capabilities of individual employees, the ability of the organization to exploit that knowledge is of primary significance. Rass et al. (2013) address this concept under the term social capital, focusing specifically on its importance in the context of open innovation. This ability of economic entities to recognize and assimilate new knowledge and then to apply it in relevant context is the determining factor in the diffusion of any innovation.

\section{Open Service Innovation Source and Diffusion Barriers}

While significant research effort has addressed open innovation from a products perspective, there has been limited attention to open service innovation. The significant differences between tangible products on the one hand and intangible outputs such as most services argue for attention to service innovation specifically. Chesbrough has acknowledged this need with the publication of his 2006 article with Spohrer (Chesbrough and Spohrer, 2006) and his subsequent book in 2010 (Chesbrough, 2010). Chesbrough (2011b) has argued that service innovation in general and open service innovation in particular may be a way to avoid what he calls the commodity trap whereby it is increasingly difficult for product-focused strategies to create lasting distinctive market positions. A few studies (e.g., Gianiodis et al., 2014; Virlée et al., 2015) have attempted to assess innovation practices among service firms using case methodologies, and a recent special issue in the Journal of Product Innovation Management (volume 35, issue 5, September 2018) presented several papers exploring open service innovation. One very recent study explored the use of different types of proximity to overcome barriers to the creation of collaborative innovations (Ooms and Piepenbrink, 2020). In those cases examined, proximity allowed the bridging of significant barriers, but the resulting innovations may have been highly specialized to the complex situations for which they were developed, inhibiting further diffusion. Although scholarly interest in open innovation in general and open service innovation specifically has increased dramatically, there has been 


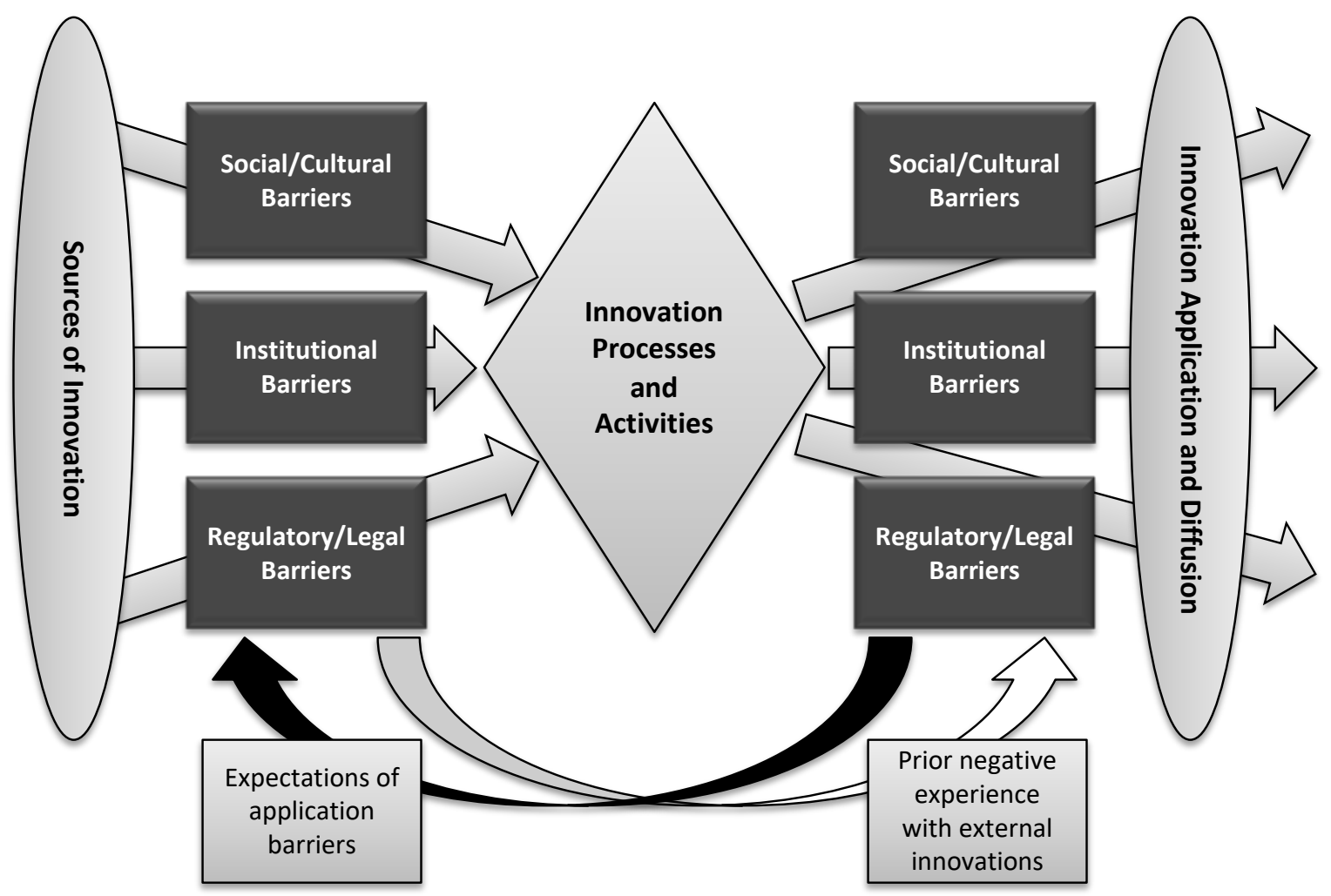

Figure 1. Barriers to Open Service Creation and Diffusion

relatively limited attention paid to the barriers that arise when innovators attempt to apply service innovations beyond the immediate context of their development.

These difficulties include factors inhibiting the dissemination of service innovations as well as factors impeding the use of outside information in the creation of innovative service offerings. The barriers to each of these aspects of openness are likely to be similar. In particular, we argue that the service domain in particular, with its deeper contextual embeddedness, as implied by collaborative value creation perspectives such as in Moeller et al. (2013) will exhibit strong interactions between front-end and back-end barriers to openness due to the importance of customer involvement in co-creation and the perishability of services.

The factors that limit the sources of information used in service innovation efforts and the application of service innovations beyond the local context within which they are created can be distilled into three critical dimensions. Social/cultural differences may constrain the use of particular service delivery models because of norms and expectations regarding acceptable modes of interaction between members of society. Institutional barriers result from difference between organizations in terms of their standard operating practices, interrelations between elements of their supply chains, or domain differences regarding the types of services and related products that they provide. Regulatory differences may create legal obstructions to the spread of innovative services because they conflict with legal requirements in a particular market. These factors are portrayed graphically in figure 1 .

The social/cultural dimension captures aspects of the service context relating to the society within which it is to be applied. This dimension includes norms regarding interactions between people that may greatly impede or even prevent certain approaches to service delivery. Such cultural differences vary regionally and nationally, and in many locations there may be substantial 
divergence in social norms and expectations from town to town or village to village.

One aspect of the service domain that may present particularly difficult barriers to the application of open innovation approaches and to innovation diffusion in general is the fact that most services involve a significant degree of co-creation (Payne et al., 2008; Spohrer and Maglio, 2008; Vargo et al., 2008; Gustafsson et al., 2012; Oertzen et al., 2018). This co-creation may be through user involvement (Chen et al., 2009; Gustafsson et al., 2012), but also co-creation with third parties such as consultants (Pinto et al., 2017). This high degree of co-creation implies that social/cultural barriers and institutional barriers will likely interact when present. Such interaction makes the application of externally developed ideas even more fraught than would either barrier alone. The perishability and inseparability of services (cf. Vargo and Lusch, 2004) may exacerbate such issues, since it is extremely difficult if not outright impossible to transport service delivery capability to geographically disparate markets should offerings be discovered to be incompatible with local market demand, institutional capabilities, or regulatory environments.

Cultural impacts have been considered in the context of research and development broadly, but historically such studies have taken a product-centric view or conflated products and services with limited distinction of differentiating factors (e.g., Albach, 1994). One study addresses the impact of culture on the diffusion of e-government (Carter and Weerakkody, 2008), but the primary dimensions of distinction in that study were access and skill with electronic communication technologies rather than cultural acceptance. The fact that the study compared two relatively similar societies, the United States and the United Kingdom, may explain the limited differences found. It is also possible that in some cases users will object to and refuse to participate in innovation efforts that require significant user interaction (Mani and Chouk, 2018).

Nonetheless, it is likely that cultural differences will hinder the spread of some approaches to service delivery. For example, a restaurant that serves all customers in a single queue and maintains a single dining space for all will encounter significant issues in adapting that model for Middle Eastern markets where gender mixing is not accepted (Murphy, 2009). Another example of such cultural variation can be seen in McDonald's cafés in Spain, France, and other coffee-culture parts of Europe (Edwards, 2011). These cafés are much more akin to traditional European cafés, including street ambiance and a less rushed sensibility, than to the North American McCafé (Hughlett, 2009) offerings, which serve primarily to avoid attrition of food sales by providing higher quality coffee within the standard North American McDonald's service system.

Additional differences arise between tangible product innovations and service innovations with respect to consumer utilization. While products are often designed with specific functions in mind, end users often appropriate them in ways that are quite different than those envisioned by the designers. Research from the structuration theory literature points out some salient examples of disparate appropriations of technology even across a relatively homogeneous set of users. Barley's (1986) exploration of the work of radiology departments details such appropriation of tangible technological products in ways that run counter to the technological imperative. Partial support has been found for the technological imperative. For example, in a study of the impact of technology on organizational structure, there was a significant impact of technology, though in many cases culture and norms were found to play a role (Grimes and Klein, 1973).

As with all of three factors discussed here, institutional factors affect both product and service innovation. Institutional knowledge has been found to impact the diffusion of innovations (Attewell, 1992), indicating the importance of absorptive capacity. However, the impact of institutional factors on services are likely to play out differently in a service context because of the significant difference between the manufacturing and distribution processes for products and the service delivery requirements of services (Hill, 1977). While there is likely an impact from the "not 
invented here" syndrome in the adoption of many processes such as those involved in service delivery, a more significant source of institutional barriers to the application of external service innovations is differences in the type of service being delivered.

Some service issues may seem similar at first blush, but differences in the underlying service being delivered may render innovations in one domain very difficult to apply in another. For example, queuing issues in a fast food restaurant may be dramatically different than those in a construction context or a financial services firm. In order for open innovation to be attractive, the work required to adapt the innovative concepts and ideas received from external sources for local use must be sufficiently lower than the work required to make similar improvements internally. In addition, the work required to produce valuable innovations for external consumption must be low enough that the remuneration, whatever form that remuneration might take, represents attractive compensation for the effort. Thus, when domain differences are more salient, open innovation becomes less attractive.

The final dimension we propose is that of legal or regulatory barriers. Regulatory barriers to diffusion have been noted in the literature since the 1970s from a technology diffusion perspective, including Oster and Quigley's study of housing codes and technical progress in construction (1977). While legal and regulatory issues often play a role in the production and sale of tangible goods, the impact of such constructs on service delivery may be more significant. Global experiences with encryption technologies may be instructive here. The issues that Research in Motion (RIM) encountered with respect to its messaging services in Saudi Arabia (Coldewey, 2010) required a different approach to service delivery than the company used elsewhere. Because of a regulatory requirement that the kingdom be able to access any messages sent within its borders, RIM was required to give user codes for Saudi customers to the authorities in Saudi Arabia. While the Saudi Arabia case was quite public, RIM faced similar issues in a number of countries (Shah, 2010; Skinner, 2010) that held such concerns, including China and the United States. Nonetheless, RIM (later renamed BlackBerry) has always maintained that only the business using the devices has the ability to give direct access to encrypted communications. Bogers, Chesbrough, and Moedas (2018) argues that public authorities (e.g., the European Commission), in addition to funding innovation that may face substantial uncertainty, should help funded companies "navigate the complexities of regulation" and "avoid regulation becoming a major obstacle" to open innovation (p. 11).

These three dimensions capture much of the difference in terms of adoption barriers between service and product innovation diffusion. While the two domains are somewhat similar, and they often share similarities that outweigh their differences, we contend that there are sufficient dissimilarities between the two that a tailored approach is apt to provide significant new insights. Thus, we take something of a synthesis approach, but with elements of distinction/demarcation.

\section{Discussion and Directions for Future Research}

Given the differences between services and products, greater attention to the factors that influence the utilization of open innovation in a service context is of significant interest for service businesses. The proliferation of business models in which products are tied to services makes such research of significant interest more broadly, as well. In order to address open service innovation adequately, it is necessary for researchers to attend to the differences between services, which are less tangible and more tightly bound to ongoing processes, and products, which are generally tangible and relatively severable from their immediate production context.

One additional element that requires attention when addressing service innovation in general 
and open service innovation specifically is the question of level of analysis. While many services will be consumed primarily at the micro level of the individual, meso- and macro-level issues will often play important roles. Meso-level constructs will be prominent in assessing institutional barriers, while macro- or national/societal-level variables will be dominant when addressing most regulatory or legal barriers. Beyond such likely dominance, there may be other interactions between open service innovation models, service innovation diffusion, and level of analysis that future research may uncover. The link between service and product innovations may also be a fruitful line of investigation, presenting possibilities for businesses to create closer relationships with customers such that they face reduced attrition and benefit from greater information flow that may facilitate further innovative product and service development.

\section{References}

Abrahamson, E. \& Rosenkopf, L. (1993). Institutional and Competitive Bandwagons: Using Mathematical Modeling as a Tool to Explore Innovation Diffusion. Academy of Management Review, 18, 487-517.

Abramovitz, M. (1986). Catching up, Forging Ahead, and Falling Behind. Journal of Economic History, 46, 385-406.

Agarwal, R., Selen, W., Roos, G., \& Green, R. (Eds.). (2015). The Handbook of Service Innovation. Springer.

Albach, H. (1994). Culture and Technical Innovation: A Cross-Cultural Analysis and Policy Recommendations, Walter de Gruyter.

Alexiev, A., Tjemkes, B., Bahlmann, M., de Man, A. P., \& Siamar, H. (2015). Open Service Innovation: Literature Review and Directions for Future Research. In The Handbook of Service Innovation (pp. 53-74). Springer, London.

Amabile, T. M., \& Pratt, M. G. (2016). The Dynamic Componential Model of Creativity and Innovation in Organizations: Making Progress, Making Meaning. Research in Organizational Behavior, 36, 157-183.

Anderson, N., Potočnik, K., \& Zhou, J. (2014). Innovation and Creativity in Organizations: A State-of-the-science Review, Prospective Commentary, and Guiding Framework. Journal of Management, 40(5), 1297-1333.

Argote, L. \& Ingram, P. (2000). Knowledge Transfer: A Basis for Competitive Advantage in Firms. Organizational Behavior and Human Decision Processes, 82, 150-169.

Arrow, K. (1962). Economic Welfare and the Allocation of Resources for Invention. The Rate and Direction of Inventive Activity: Economic and Social Factors. NBER.

Attewell, P. (1992). Technology Diffusion and Organizational Learning: The Case of Business Computing. Organization Science, 3, 1-19.

Baines, T. S., Lightfoot, H. W., Benedettini, O., \& Kay, J. M. (2009). The Servitization of Manufacturing: A Review of Literature and Reflection on Future Challenges. Journal of Manufacturing Technology Management, 20(5), 547-567.

Barley, S. R. (1986). Technology as an Occasion for Structuring - Evidence from Observations of Ct Scanners and the Social-Order of Radiology Departments. Administrative Science Quarterly, 
$31,78-108$.

Barney, J. B. (2001). Resource-Based Theories of Competitive Advantage: A Ten-Year Retrospective on the Resource-Based View. Journal of Management, 27, 643-650.

Barras, R. (1986). Towards a Theory of Innovation in Services. Research Policy, 15, 161-173.

Benkler, Y. (2002). Coase's Penguin, or, Linux and "The Nature of the Firm". Yale Law Journal, 369-446.

Bogers, M., Chesbrough, H., \& Moedas, C. (2018). Open Innovation: Research, Practices, and Policies. California Management Review, 60(2), 5-16.

Bogers, M. \& West, J. (2012). Managing Distributed Innovation: Strategic Utilization of Open and User Innovation. Creativity and Innovation Management, 21, 61-75.

Brodie, R. J., Hollebeek, L. D., Jurić, B., \& Ilić, A. (2011). Customer Engagement: Conceptual Domain, Fundamental Propositions, and Implications for Research. Journal of Service Research, 14(3), 252-271.

Brown, S. L. \& Eisenhardt, K. M. (1995). Product Development: Past Research, Present Findings, and Future Directions. The Academy of Management Review, 20, 343-378.

Carter, L. \& Weerakkody, V. (2008). E-Government Adoption: A Cultural Comparison. Information Systems Frontiers, 10, 473-482.

Castro, L. M., Montoro-Sanchez, A. \& Ortiz-De-Urbina-Criado, M. (2011). Innovation in Services Industries: Current and Future Trends. Service Industries Journal, 31, 7-20.

Chandler, A. D. (1962). Strategy and Structure: Chapters in the History of the Industrial Enterprise, Cambridge, MA, MIT Press.

Chen, J.-S., Tsou, H. T. \& Huang, A. Y.-H. (2009). Service Delivery Innovation Antecedents and Impact on Firm Performance. Journal of Service Research, 12, 36-55.

Chesbrough, H. (2003a). The Era of Open Innovation. MIT Sloan Management Review, 44, 35-41.

Chesbrough, H. (2003b). Open Innovation: The New Imperative for Creating and Profiting from Technology, Cambridge, MA, Harvard Business Press.

Chesbrough, H. (2004). Managing Open Innovation. Research-Technology Management, 47, 23-26.

Chesbrough, H., Vanhaverbeke, W., \& West, J. (Eds.). (2006). Open Innovation: Researching a New Paradigm. Oxford University Press.

Chesbrough, H. (2010). Open Services Innovation: Rethinking Your Business to Grow and Compete in a New Era, San Francisco, John Wiley \& Sons.

Chesbrough, H. (2011a). Bringing Open Innovation to Services. MIT Sloan Management Review, 52, 85-90.

Chesbrough, H. (2011b). The Case for Open Services Innovation: The Commodity Trap. California Management Review, 53, 5-20.

Chesbrough, H. (2011c). Open Services Innovation: Rethinking Your Business to Grow and Compete in a New Era. John Wiley \& Sons. 
Chesbrough, H. \& Crowther, A. (2006). Beyond High Tech: Early Adopters of Open Innovation in Other Industries. $R \& D$ Management, 36, 229-236.

Chesbrough, H. \& Spohrer, J. (2006). A Research Manifesto for Services Science. Communications of the ACM, 49, 35-40.

Chesbrough, H., Vanhaverbeke, W. \& West, J. (2006). Open Innovation: Researching a New Paradigm, Oxford, Oxford University Press.

Chesbrough, H., Lettl, C., \& Ritter, T. (2018). Value Creation and Value Capture in Open Innovation. Journal of Product Innovation Management, 35(6), 930-938.

Cohen, W. M. \& Levinthal, D. A. (1990). Absorptive Capacity: A New Perspective on Learning and Innovation. Administrative Science Quarterly, 35, 128-152.

Coldewey, D. (2010). Rim Reportedly Bows to Pressure from Saudi Arabia, Hands over Blackberry Access [Online]. TechCrunch. Available: http://techcrunch.com/2010/08/10/rim-reportedlybows-to-pressure-from-saudi-arabia-hands-over-blackberry-access/.

Coombs, R. \& Miles, I. (2000). Innovation, Measurement and Services: The New Problematique. In: METCALFE, J. S. \& MILES, I. (eds.) Innovation Systems in the Service Economy. Springer US.

Crossan, M. M. \& Apaydin, M. (2010). A Multi-Dimensional Framework of Organizational Innovation: A Systematic Review of the Literature. Journal of Management Studies, 47, 11541191.

Dahlander, L. \& Gann, D. M. (2010). How Open Is Innovation? Research Policy, 39, 699-709.

Damanpour, F. (1991). Organizational Innovation: A Meta-Analysis of Effects of Determinants and Moderators. Academy of Management Journal, 34, 555-590.

De Faria, P., Lima, F., \& Santos, R. (2010). Cooperation in Innovation Activities: The Importance of Partners. Research Policy, 39(8), 1082-1092.

De Vries, E. J. (2006). Innovation in Services in Networks of Organizations and in the Distribution of Services. Research Policy, 35, 1037-1051.

Djellal, F. \& Gallouj, F. (2001). Patterns of Innovation Organisation in Service Firms: Postal Survey Results and Theoretical Models. Science and Public Policy, 28, 57-67.

Djellal, F. \& Gallouj, F. (2013). The Productivity Challenge in Services: Measurement and Strategic Perspectives. Service Industries Journal, 33, 282-299.

Downs, G. W., Jr. \& Mohr, L. B. (1976). Conceptual Issues in the Study of Innovation. Administrative Science Quarterly, 21, 700-714.

Drejer, I. (2004). Identifying Innovation in Surveys of Services: A Schumpeterian Perspective. Research Policy, 33, 551-562.

Droege, H., Hildebrand, D. \& Forcada, M. (2009). Innovation in Services: Present Findings, and Future Pathways. Journal of Service Management, 20, 131-155.

Edwards, J. M. (2011). Mccafe in Paris: Way Better Than Mccafe in the States [Online]. Serious eats. Available: http://www.seriouseats.com/2011/04/mccafe-in-paris-europe-fast-food-coffeeshop.html.

Edwards, M., Logue, D., \& Schweitzer, J. (2015). Towards an Understanding of Open Innovation 
in Services: Beyond the Firm and Towards Relational Co-Creation. In The Handbook of Service Innovation (pp. 75-90). Springer, London.

Eisenhardt, K. M. (1989). Agency Theory: An Assessment and Review. Academy of Management Review, 14, 57-74.

Evangelista, R. \& Savona, M. (2003). Innovation, Employment and Skills in Services. Firm and Sectoral Evidence. Structural Change and Economic Dynamics, 14, 449-474.

Evangelista, R., \& Savona, M. (2010). Innovation and Employment in Services. The Handbook of Innovation and Services: A Multi-Disciplinary Perspective. New-York: Edward Elgar Publishing, 367-391.

Faems, D., Van Looy, B. \& Debackere, K. (2005). Interorganizational Collaboration and Innovation: Toward a Portfolio Approach. Journal of Product Innovation Management, 22, 238-250.

Feller, J., \& Fitzgerald, B. (2002). Understanding Open Source Software Development. London: Addison-Wesley.

Fernandes, C., Ferreira, J., \& Peris-Ortiz, M. (2019). Open Innovation: Past, Present and Future Trends. Journal of Organizational Change Management, 32(5), 578-602.

Fernandes, T., \& Remelhe, P. (2016). How to Engage Customers in Co-Creation: Customers' Motivations for Collaborative Innovation. Journal of Strategic Marketing, 24(3-4), 311-326.

Fischer, A. (2009). A Practical Introduction to Service Innovation. In: KAZI, A. S., WOLF, P. \& TROXLER, P. (eds.) Supporting Service Innovation through Knowledge Management: Practical Insights \& Case Studies. Swiss Knowledge Management Forum.

Froehle, C., Roth, A., Chase, R. and Voss, C. (2000). Antecedents of new service development effectiveness: an exploratory examination of strategic operations choices. Journal of Service Research, 3(1), pp.3-17.

Füller, J. (2010). Refining Virtual Co-Creation from a Consumer Perspective. California Management Review, 52(2), 98-122.

Gadrey, J., Gallouj, F. \& Weinstein, O. (1995). New Modes of Innovation - How Services Benefit Industry. International Journal of Service Industry Management, 6, 4-16.

Gallouj, F. \& Savona, M. (2009). Innovation in Services: A Review of the Debate and a Research Agenda. Journal of Evolutionary Economics, 19, 149-172.

Gallouj, F. \& Weinstein, O. (1997). Innovation in Services. Research Policy, 26, 537-556.

Ganz, W., Satzger, G. \& Schultz, C. (2012). Methods in Service Innovation: Current Trends and Future Perspectives, Germany, Fraunhofer Verlag.

Gianiodis, P.T., Ettlie, J.E. and Urbina, J.J., 2014. Open Service Innovation in the Global Banking Industry: Inside-Out Versus Outside-In Strategies. Academy of Management Perspectives, 28(1), pp.76-91.

Giannopoulou, E., Yström, A. \& Ollila, S. (2011). Turning Open Innovation into Practice: Open Innovation Research through the Lens of Managers. International Journal of Innovation Management, 15, 505-524.

Gould, R. (2012). Open Innovation and Stakeholder Engagement. Journal of Technology Management \& Innovation, 7(3), 1-11. 
Grant, R. M. (1996a). Prospering in Dynamically-Competitive Environments: Organizational Capability as Knowledge Integration. Organization Science, 7, 375-387.

Grant, R. M. (1996b). Toward a Knowledge-Based Theory of the Firm. Strategic Management Journal, 17, 109-122.

Grimes, A. J. \& Klein, S. M. (1973). Technological Imperative - Relative Impact of Task Unit, Modal Technology, and Hierarchy on Structure. Academy of Management Journal, 16, 583-597.

Gustafsson, A., Kristensson, P. \& Witell, L. (2012). Customer Co-Creation in Service Innovation: A Matter of Communication? Journal of Service Management, 23, 311-327.

Henkel, J. (2006). Selective Revealing in Open Innovation Processes: The Case of Embedded Linux. Research Policy, 35(7), 953-969.

Hill, T. P. (1977). On Goods and Services. Review of Income and Wealth, 23, 315-338.

Howells, J. (2000). Innovation \& Services: New Conceptual Frameworks, Centre for Research on Innovation and Competition, The University of Manchester.

Huang, F., Rice, J., Galvin, P., \& Martin, N. (2014). Openness and Appropriation: Empirical Evidence from Australian Businesses. IEEE Transactions on Engineering Management, 61(3), 488-498.

Hughlett, M. (2009). Mcdonald's Coffee Plan Goes Full-Steam Ahead. Breakfast Dollar Menu on Way to Going National [Online]. Chicago Tribune. Available: http://articles.chicagotribune.com/200911-13/news/0911120966_1_mccafe-dollar-menu-new-drinks.

Huizingh, E. (2011). Open Innovation: State of the Art and Future Perspectives. Technovation, 31, 2-9.

Hurmelinna, P., Kyläheiko, K., \& Jauhiainen, T. (2007). The Janus Face of the Appropriability Regime in the Protection of Innovations: Theoretical Re-Appraisal and Empirical Analysis. Technovation, 27(3), 133-144.

Inkpen, A. C. \& Tsang, E. W. K. (2005). Social Capital, Networks, and Knowledge Transfer. Academy of Management Review, 30, 146-165.

Jaakkola, E., \& Alexander, M. (2014). The Role of Customer Engagement Behavior in Value Co-Creation: A Service System Perspective. Journal of Service Research, 17(3), 247-261.

Kambil, A., Ginsberg, A., \& Bloch, M. (1996). Re-inventing Value Propositions. Information Systems Working Papers Series. Accessed 27 April 2021. https://archivefda.dlib.nyu.edu/jspui/ bitstream/2451/14205/1/IS-96-21.pdf

Kambil, A., Friesen, G. B., \& Sundaram, A. (1999). Co-Creation: A New Source of Value. Outlook Magazine, 3(2), 23-29.

Katz, R. \& Allen, T. J. (1982). Investigating the Not Invented Here (NIH) Syndrome - a Look at the Performance, Tenure, and Communication Patterns of 50 R-and-D Project Groups. $R \& D$ Management, 12, 7-19.

Kedia, B. L. \& Bhagat, R. S. (1988). Cultural Constraints on Transfer of Technology across Nations: Implications for Research in International and Comparative Management. Academy of Management Review, 13(4), 559-571.

Kogut, B. \& Zander, U. (1992). Knowledge of the Firm, Combinative Capabilities, and the 
Replication of Technology. Organization Science, 3, 383-397.

Kohler, M., Feldmann, N., Habryn, F. \& Satzger, G. Service Innovation Analytics: Towards Assessment and Monitoring of Innovation Capabilities in Service Firms. In: HICSS, ed. 46th Hawaii International Conference on System Sciences, 7-10 Jan. 2013. 1347-1356.

Kroh, J., Luetjen, H., Globocnik, D., \& Schultz, C. (2018). Use and Efficacy of Information Technology in Innovation Processes: The Specific Role of Servitization. Journal of Product Innovation Management, 35(5), 720-741.

Lancaster, K. J. (1966). A New Approach to Consumer Theory. Journal of Political Economy, 74, 132-157.

Lichtenthaler, U. (2011). Open Innovation: Past Research, Current Debates, and Future Directions. Academy of Management Perspectives, 25, 75-93.

Lichtenthaler, U. \& Lichtenthaler, E. (2009). A Capability-Based Framework for Open Innovation: Complementing Absorptive Capacity. Journal of Management Studies, 46, 1315-1338.

Lusch, R. F., \& Nambisan, S. (2015). Service innovation: A Service-Dominant Logic Perspective. MIS Quarterly, 39(1), 155-176.

Lusch, R. F., \& Vargo, S. L. (2014). Service-Dominant Logic: Premises, Perspectives, Possibilities. Cambridge University Press.

Mani, Z., \& Chouk, I. (2018). Consumer Resistance to Innovation in Services: Challenges and Barriers in the Internet of Things Era. Journal of Product Innovation Management, 35(5), 780-807.

March, J. G. (1991). Exploration and Exploitation in Organizational Learning. Organization Science, 2, 71-87.

March, J. G. \& Simon, H. A. (1958). Organizations, New York, Wiley.

Menor, L. J. \& Roth, A. V. (2007). New Service Development Competence in Retail Banking: Construct Development and Measurement Validation. Journal of Operations Management, 25, 825-846.

Miller, D. \& Friesen, P. H. (1982). Innovation in Conservative and Entrepreneurial Firms: Two Models of Strategic Momentum. Strategic Management Journal, 3, 1-25.

Moeller, S., Ciuchita, R., Mahr, D., Odekerken-Schröder, G. \& Fassnacht, M. (2013). Uncovering Collaborative Value Creation Patterns and Establishing Corresponding Customer Roles. Journal of Service Research, 16, 471-487.

Murphy, C. (2009). Saudi Arabia: Dining by Gender [Online]. The Christian Science Monitor. Available: http://www.csmonitor.com/World/Global-News/2009/0422/saudi-arabia-dining-bygender.

Nijssen, E. J., Hillebrand, B., Vermeulen, P. a. M. \& Kemp, R. G. M. (2006). Exploring Product and Service Innovation Similarities and Differences. International Journal of Research in Marketing, 23, 241-251.

Nonaka, I. (1991). The Knowledge-Creating Company. Harvard Business Review, 69, 96-104.

Nonaka, I. (1994). A Dynamic Theory of Organizational Knowledge Creation. Organization Science, 5, 14-37. 
Nonaka, I. \& Takeuchi, H. (1995). The Knowledge-Creating Company: How Japanese Companies Create the Dynamics of Innovation, Oxford University Press, USA.

Nonaka, I., Takeuchi, H. \& Umemoto, K. (1996). A Theory of Organizational Knowledge Creation. International Journal of Technology Management, 11, 833-845.

O'Cass, A., \& Wetzels, M. (2018). Contemporary Issues and Critical Challenges on Innovation in Services. Journal of Product Innovation Management, 35(5), 674-681.

OECD (2005). Growth in Services: Fostering Employment, Productivity and Innovation. In: DEVELOPMENT, O. F. E. C.-O. A. (ed.). Organisation for Economic Co-Operation and Development.

OECD (2007). Summary Report of the Study on Globalisation and Innovation in the Business Services Sector. In: DEVELOPMENT, O. F. E. C.-O. A. (ed.). Organisation for Economic Co-Operation and Development.

Oertzen, A. S., Odekerken-Schröder, G., Brax, S. A., \& Mager, B. (2018). Co-creating Services-Conceptual Clarification, Forms and Outcomes. Journal of Service Management, 29, 641-79.

Ollila, S. \& Elmquist, M. (2011). Managing Open Innovation: Exploring Challenges at the Interfaces of an Open Innovation Arena. Creativity and Innovation Management, 20, 273-283.

Ooms, W., \& Piepenbrink, R. (2020). Open Innovation for Wicked Problems: Using Proximity to Overcome Barriers. California Management Review, 63(2), 62-100.

Ordanini, A. \& Parasuraman, A. (2010). Service Innovation Viewed through a Service-Dominant Logic Lens: A Conceptual Framework and Empirical Analysis. Journal of Service Research, 14, 3-23.

Oster, S. M. \& Quigley, J. M. (1977). Regulatory Barriers to the Diffusion of Innovation: Some Evidence from Building Codes. The Bell Journal of Economics, 8(2), 361-377.

Osterloh, M. \& Frey, B. S. (2000). Motivation, Knowledge Transfer, and Organizational Forms. Organization Science, 11, 538-550.

Pavitt, K. (1984). Sectoral Patterns of Technical Change - Towards a Taxonomy and a Theory. Research Policy, 13, 343-373.

Payne, A. F., Storbacka, K. \& Frow, P. (2008). Managing the Co-Creation of Value. Journal of the Academy of Marketing Science, 36, 83-96.

Pinto, M., Saur-Amaral, I. \& Brito, C. (2017). Innovation Intermediaries in Service Industry: The Role of Consultancies. Journal of Innovation Management, 5(4), pp.74-102.

Pisano, G. P. (2015). You Need an Innovation Strategy. Harvard Business Review, 93(6), 44-54.

Prahalad, C. K., \& Ramaswamy, V. (2004). Co-Creation Experiences: The Next Practice in Value Creation. Journal of Interactive Marketing, 18(3), 5-14.

Prajogo, D. I. (2006). The Relationship between Innovation and Business Performance - A Comparative Study between Manufacturing and Service Firms. Knowledge and Process Management, $13,218-225$.

Randhawa, K., \& Scerri, M. (2015). Service Innovation: A Review of the Literature. In The Handbook of Service Innovation (pp. 27-51). Springer, London. 
Rass, M., Dumbach, M., Danzinger, F., Bullinger, A. C. \& Moeslein, K. M. (2013). Open Innovation and Firm Performance: The Mediating Role of Social Capital. Creativity and Innovation Management, 22, 177-194.

Robertson, T. S. \& Gatignon, H. (1998). Technology Development Mode: A Transaction Cost Conceptualization. Strategic Management Journal, 19, 515-531.

Rogers, E. M. (1962). Diffusion of Innovations, New York: Free Press.

Shah, A. (2010). Can Dubai Business Survive without the Blackberry? [Online]. Time. Available: http://www.time.com/time/world/article/0,8599,2008632,00.html.

Simon, H. A. (1991). Bounded Rationality and Organizational Learning. Organization Science, 2, 125-134.

Skinner, C. A. (2010). Rim Holds Talks with UAE and Saudi Arabia [Online]. NetworkWorld. Available: http://www.networkworld.com/news/2010/080610-rim-holds-talks-with-uae.html.

Spohrer, J. \& Maglio, P. P. (2008). The Emergence of Service Science: Toward Systematic Service Innovations to Accelerate Co-Creation of Value. Production and Operations Management, 17, 238-246.

Sundbo, J. (1997). Management of Innovation in Services. Service Industries Journal, 17, 432-455.

Teece, D. J. (1992). Competition, Cooperation, and Innovation - Organizational Arrangements for Regimes of Rapid Technological-Progress. Journal of Economic Behavior \& Organization, 18, $1-25$.

Tian, M., Deng, P., Zhang, Y., \& Salmador, M. P. (2018). How Does Culture Influence Innovation? A Systematic Literature Review. Management Decision, 56(5), 1088-1107.

Tidd, J. \& Hull, F. M. (2003). Service Innovation: Organizational Responses to Technological Opportunities \& Market Imperatives, Imperial College Press.

Tsai, W. P. \& Ghoshal, S. (1998). Social Capital and Value Creation: The Role of Intrafirm Networks. Academy of Management Journal, 41, 464-476.

Vandermerwe, S., \& Rada, J. (1988). Servitization of Business: Adding Value by Adding Services. European Management Journal, 6(4), 314-324.

Vargo, S. L. \& Lusch, R. F. (2004). The Four Service Marketing Myths: Remnants of a Goods-Based, Manufacturing Model. Journal of Service Research, 6, 324-335.

Vargo, S. L., Maglio, P. P. \& Akaka, M. A. (2008). On Value and Value Co-Creation: A Service Systems and Service Logic Perspective. European Management Journal, 26, 145-152.

Verhoef, P. C., Reinartz, W. J., \& Krafft, M. (2010). Customer Engagement as a New Perspective in Customer Management. Journal of Service Research, 13(3), 247-252.

Virlee, J., Hammedi, W. and Parida, V., 2015. Open Innovation Implementation in the Service Industry: Exploring Practices, Sub-Practices and Contextual. Journal of Innovation Management, 3(2), pp.106-130.

Von Hippel, E. (2005). Democratizing Innovation, Cambridge, MA, MIT Press.

Vuori, T. O., \& Huy, Q. N. (2016). Distributed Attention and Shared Emotions in the Innovation Process: How Nokia Lost the Smartphone Battle. Administrative Science Quarterly, 61(1), 9-51.

Walker, G. \& Weber, D. (1984). A Transaction Cost Approach to Make-or-Buy Decisions. 
Administrative Science Quarterly, 29, 373-391.

Walker, G. \& Weber, D. (1987). Supplier Competition, Uncertainty, and Make-or-Buy Decisions. Academy of Management Journal, 30, 589-596.

Wallace, J. C., Butts, M. M., Johnson, P. D., Stevens, F. G., \& Smith, M. B. (2016). A Multilevel Model of Employee Innovation: Understanding the Effects of Regulatory Focus, Thriving, and Employee Involvement Climate. Journal of Management, 42(4), 982-1004.

Wang, H., \& Chen, W. R. (2010). Is Firm-Specific Innovation Associated with Greater Value Appropriation? The Roles of Environmental Dynamism and Technological Diversity. Research Policy, 39(1), 141-154.

Wernerfelt, B. (1984). A Resource-Based View of the Firm. Strategic Management Journal, 5, 171-180.

West, J., \& Bogers, M. (2014). Leveraging External Sources of Innovation: A Review of Research on Open Innovation. Journal of Product Innovation Management, 31(4), 814-831.

Williamson, O. E. (1981). The Economics of Organization - The Transaction Cost Approach. American Journal of Sociology, 87, 548-577.

Wittke, V., \& Hanekop, H. (2011). New Forms of Collaborative Innovation and Production on the Internet. Universitätsverlag Göttingen. 


\section{Biographies}

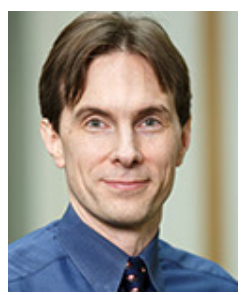

holds one patent.

CRediT Statement:

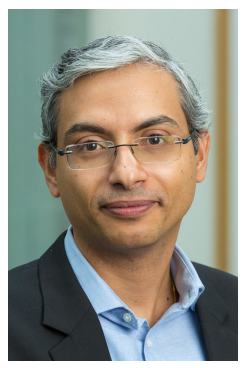

Karthik Sankaranarayanan. Karthik Sankaranarayanan is Associate Professor of Analytics and Operations Management at Ontario Tech University, Canada. Dr. Sankaranarayanan received his Ph.D. in Management from the University of Lugano, Switzerland in 2011 and was visiting researcher at the New England Complex Systems Institute, Cambridge, MA. His research encompasses the study of complex adaptive systems using a variety of methods including simulation, agent-based modeling, experimental methods and other computational tools. Dr. Sankaranarayanan is an interdisciplinary researcher who uses machine-learning algorithms to build better decision-aid models.

CRediT Statement: Writing - Original Draft, Writing - Review \& Editing

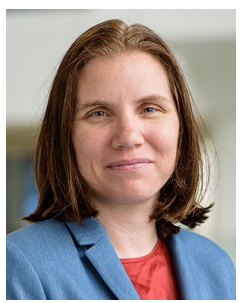

Jennifer Percival. Jennifer Percival is the Associate Dean of the Manning School of Business at the University of Massachusetts, Lowell. She received her BMath (Operations Research) in 2001 and PhD (Engineering - Management Sciences) in 2004 from the University of Waterloo. Her research began with evaluating the impact of organizational strategy and manufacturing technology implementation and has recently focused on innovation management and the effective use and integration of technology to support service industries, in particular education and healthcare. She is also actively involved in research surrounding the use of patient journey modeling and process modeling techniques to support innovation, change management, and technology integration in services. Her research has involved faculty colleagues and students across all disciplines on campus, at other universities and partner community colleges, and with multiple industry collaborators. Dr. Percival is currently serving on the board of directors of the Society of Health Systems and on the Associate Dean Advisory Group steering committee for AACSB.

CRediT Statement: Writing - Original Draft 